\title{
TACNA Y ARICA: VISUALIZACIONES, PLEBISCITO Y NUEVA FRONTERA EN LA UNIÓN DE VALPARAÍSO, 1922*
}

\author{
TACNA AND ARICA: VISUALISATIONS, PLEBISCITE \\ AND NEW BORDER IN VALPARAÍSO'S LA UNIÓN, 1922 \\ Pablo Aravena ${ }^{* *}$ y Eduardo Cobos***
}

\begin{abstract}
La presente investigación tiene como propósito indagar ciertos aspectos relacionados con el discurso nacional de principios del siglo XX, centrando nuestra atención en un amplio reportaje acerca de Arica y Tacna publicado por entregas en el diario La Unión de Valparaíso en diciembre de 1922, momento de tensión diplomática entre Perú y Chile cuyo entorno era una posible definición plebiscitaria de los límites de la nueva frontera norte. Este tipo de reportajes -que basaban su efectividad en la conjunción entre imágenes fotográficas y textos-fueron utilizados como una postura periodística que se correspondía con la alianza practicada entre las políticas de chilenización del Estado y las empresas editoriales para crear y fomentar un imaginario nacionalista postguerra del Pacífico. En este sentido, la intencionalidad estratégica del reportaje de La Unión consistió en replicar una idea general preconcebida, estereotipada, que daba a entender la conveniencia de que los territorios ocupados y aún en disputa continuaran bajo el dominio de Chile, debido a que el país era el más apto para ejercer el progreso y la modernización. Estos intereses se habían tornado esenciales para la elite porteña, que fue la tribuna hacia donde apuntó en especial el diario.
\end{abstract}

Palabras claves: Plebiscito, reportaje periodístico, chilenización, nueva frontera norte.

This investigation aims to look at certain issues related to Chile's national discourse at the beginning of the twentieth century, focusing our attention on a wide-ranging report about Arica and Tacna published in installments in the newspaper La Unión in December 1922. A moment of diplomatic tension between Peru and Chile whose backdrop was the possible definition of the new northern border's boundaries through a plebiscite. This kind of report-whose effectiveness was based on bringing photographic images and text-was used as a journalistic position that corresponded with the alliance between the State and the press over the policies of "Chilenisation" to create and encourage nationalist sentiment after the War of the Pacific. In this sense, the report's strategic intention in La Unión consisted in replicating a preconceived and stereotypical general idea that held that it was convenient for the occupied territories still in dispute to continue under Chilean rule since the country was better suited to bringing progress and modernization. These interests had become essential for Valparaíso's elite, the audience at which the newspaper was aiming in particular.

Key words: Plebiscite, journalistic reports, Chilenisation, the new northern border.

\section{Introducción}

El triunfo en la Guerra del Pacífico (1879-1883) le había posibilitado a Chile anexar territorios de Perú y Bolivia, y con ello gestionar con mayor beneficio la explotación y comercialización del salitre con capital extranjero. Y a medida que la minería proporcionó inesperados aportes al erario público, el Estado se interesó mucho más en integrar las nuevas fronteras al poder central, para ello reforzó su presencia con instituciones administrativas, el poblamiento y el enclave militar limítrofe (Collier y Sater 1999). En todo caso, las desavenencias entre Chile y Perú fueron siempre fluctuantes y conflictivas, teniendo a comienzos del siglo XX periodos de verdaderas crisis diplomáticas, que implicó la ruptura de relaciones en 1909 y un distanciamiento casi total al verificarse, en 1918, el retiro de sus cónsules en ciudades y puertos estratégicos de ambos países (Ruz, Meza y Galdames 2018). Y se habían hecho, de igual modo, más evidentes las diferencias entre chilenos y peruanos desde el Centenario de la Independencia exacerbándose el nacionalismo (Díaz y Pizarro 2004) con demostraciones de xenofobia y racismo, no exentas de violencia, en los territorios ocupados (González et al. 1993); así como un intento más radical de profundizar la chilenización por medio de dispositivos educacionales, militares y cívicos, queriendo con esto persuadir a la población de que las instituciones chilenas eran seguros

\footnotetext{
* Resultado de Proyecto Fondecyt 1171499.

** Universidad de Valparaíso. Instituto de Historia y Ciencias Sociales. Correo electrónico: pablo.aravena@uv.cl

*** Universidad de Valparaíso. Programa Magíster en Estudios Históricos: Cultura y Sociedad en Chile y América Latina. Correo electrónico: eduardo.cobos@uv.cl
} 
garantes de progreso y civilización (Cádiz 2013; Galdames, Ruz y Meza 2018).

A inicios de los años veinte, el gobierno de Perú -valorando la decisión de Estados Unidos, propuesta por el presidente Wilson en los llamados "Catorce Puntos"- estipuló que se habían establecido nuevas condiciones para los reclamos en torno a la recuperación de los territorios que estaban bajo el dominio chileno (Tarapacá, Arica y Tacna). La opinión pública peruana se inclinaba a dejar sin efecto lo pactado en el Tratado de Ancón (1883), argumentándose que el vencedor en la contienda bélica no lo había respetado al haber quedado sin efecto un plebiscito en 1894 que dirimiera el destino de Arica y Tacna (Ruz, Meza y Galdames 2018). Por su parte, el gobierno de Chile, a fines de 1921, pese a no tener la total certeza de que la negociación le sería favorable, dio los primeros pasos para un acercamiento con Perú. Resultado de esto, desde mayo hasta julio de 1922, se llevaron a cabo en Washington reuniones oficiales que tomaron en cuenta solo lo que estaba pendiente por resolverse del artículo tercero del Tratado. En este sentido, el acuerdo determinó que la provincia de Tarapacá quedaba en definitiva fuera de disputa y en poder de Chile, y el arbitraje norteamericano se reducía a considerar si el artículo tercero tenía vigencia, y si la tuviera a formalizar las condiciones para retomar el plebiscito (Lagos 1981). Todos estos eventos fueron cubiertos por La Unión de Valparaíso, que les dedicó especial atención debido a intereses de clase.

El diario había sido fundado en 1885, en plena época de litigios entre la Iglesia católica y el Estado, por sectores conservadores (la "Unión Católica de Chile”) (Aguirre 1946). En las primeras décadas del siglo XX, La Unión se transformó en un exponente de la prensa moderna al instaurar una eficiente “estrategia periodística" (Santa Cruz 2014:13). Las medidas modernizantes eran producto de la implementación de recientes tecnologías y concepciones vinculadas a los medios de comunicación masivos. Esto implicó una administración con sentido empresarial que adquirió un mayor financiamiento con la publicidad y el avisaje, teniendo un claro perfil de lector: sectores de la elite empresarial, financiera y comercial, y profesionales y empleados de las clases emergentes (Henríquez 2013). También se hizo indispensable la profesionalización de sus periodistas y los ajustes efectuados a lo noticioso, dando cabida a una diversidad de eventos políticosociales recogidos en una estructura más dinámica de sus páginas al incorporar versátiles y efectivos formatos de géneros periodísticos; así como la más frecuente visualización de material gráfico con imágenes fotográficas y caricaturas, siguiendo la exitosa experiencia de otros medios como las revistas magazine (Santa Cruz 2002).

Nuestra investigación, siguiendo estas directrices, ha tomado como anclaje temporal el inicio de las Conferencias de Washington de 1922. El soporte escogido ha sido las imágenes fotográficas y los textos de un extenso reportaje de La Unión de Valparaíso de diciembre de 1922, considerando que este tipo de géneros periodísticos son una fuente por la que se pueden reconstruir imaginarios colectivos que contemplan hábitos cotidianos de un complejo entramado social ${ }^{1}$.

La postura editorial de La Unión tuvo un correlato de desvalorización/invención de la nueva región a la que se quería mejorar al ser modernizada, imbricándola con el proyecto de país que delimitaba la soberanía nacional. Basados en esto, nos propusimos responder a las siguientes preguntas: ¿cómo estableció su línea editorial La Unión en relación con Arica y Tacna vinculándola a imágenes fotográficas y textos en periodo de conflictividad diplomática? ¿De qué manera fueron "leídos” estos textos e imágenes en un contexto nacional? ¿Quiénes fueron los sujetos actuantes de la elaboración de estas representaciones?

La metodología utilizada, debido a la vinculación entre palabra e imagen de los medios de comunicación masivos de la época (Rinke 2002), se basó en una lectura crítica del reportaje periodístico desde el análisis formal de los elementos que constituyen las retóricas visuales y textuales (Barthes 1986); así como la pertinencia de las delimitaciones contextuales que proporciona la historia cultural como desencadenante de los imaginarios colectivos (Chartier 1992).

\section{El reportaje de La Unión de Valparaíso}

A José E. Novoa Orellana se le encomendó la "misión" de realizar un reportaje en las ciudades de Tacna y Arica para dar a conocer in situ las opiniones del electorado en cierne del que no se conocían con exactitud sus preferencias nacionalistas ${ }^{2}$. Las entregas fueron publicadas por La Unión desde el 8 al 28 de diciembre de 1922, y en ellas -producto de amplios desplazamientos y de múltiples entrevistas- no solo se dejaba en evidencia el resultado 
del sondeo en este periodo de tensión diplomática sino que el periodista elaboró un esmerado relato en el que, a la manera de un "escritor de viajes" (Pratt 1997:375), describía aspectos vinculados directamente con la chilenización (política, educativa, cívico-militar, religiosa), los paisajes rurales y urbanos, la creciente industria agropecuaria y minera, la cotidianeidad de algunos habitantes y un recorrido en el ferrocarril internacional Arica-La Paz ${ }^{3}$. Con todo esto, se satisfacían las necesidades más urgentes de información, familiarizando al lector del diario con un espacio territorial lejano, poco conocido y muchas veces desvirtuado; y si se ganaba el plebiscito, se presentaban ciertas oportunidades que eran posibles de llevar a cabo, según fuera el interés, mediante el poblamiento, la inversión, el comercio o la industrialización. Es decir, los requisitos esenciales para la obtención de progreso y civilización que anhelaban los sectores de elite (Barros y Vergara 2007), a quienes principalmente iban dirigidas las páginas del matutino porteño.

Los editores de La Unión concibieron, paralelamente al escrito, un relato gráfico cuyo soporte fue el envío de imágenes de un diario ariqueño y la reproducción de vistas extraídas de álbumes fotográficos. Los álbumes también habían sido utilizados como modelo para toda la prensa actualizada de la época, pudiendo hacer circular un amplio repertorio de imágenes para sus contenidos; y si bien el origen del álbum se remontaba a la década de los sesenta del siglo XIX, hubo una notoria proliferación de estos con grandes tirajes a inicios del siglo XX (Leiva 2013; Fernández 2018), los que intentaban dar una gran panorámica visual del país que aspiraba a ser una nación moderna ${ }^{4}$. En este caso, La Unión le otorgó funcionalidad al conjunto de imágenes escogidas al ordenarlas y resituarlas en un nuevo contexto; y apeló a la pretendida objetividad y "transparencia de la fotografía” (Tagg 2005:52), tratándose, como en otros reportajes, más que nada de convenciones socioculturales y a una prueba de veracidad para los textos que les daban sustento (Cornejo 2012).

El primer artículo del reportaje, "Una visita a las provincias de Tacna y Arica", contiene imágenes de reuniones de festejo. En una de estas, se destaca en semicírculo a un numeroso grupo de "damas de la sociedad tacneña" que visten elegantes ropas casuales y están en actitud de juvenil distensión, algunas sonrientes, disfrutando de un día al aire libre en el frontis embanderado de la casa del
Intendente Luis Barceló Lira. Junto con ellas se encuentran las autoridades civiles y militares de Tacna y Arica, y los cónsules de Italia, España y EE.UU. (Figura 1). Este tipo de representaciones, usuales en la prensa de la época, configuró una galería de poses estereotipadas, las que sirvieron para demarcar cierta sociabilidad en los espacios públicos urbanos, procurando así resaltar el "buen tono" y las "buenas maneras" que demostraran la cultura y el comportamiento civilizado de las elites (Navarrete 2009:43). Y en este caso en particular, se aspiraba afianzar patrones a seguir impuestos por la clase dominante, lo que daba a entender que las actividades sociales en la nueva frontera se realizaban en iguales condiciones que las del centro del país.

Para este artículo, Novoa Orellana había podido tomar declaraciones a Barceló Lira en el edificio de la Intendencia de Tacna. Allí, el alto personero resumió favorablemente el desempeño de los servicios públicos que se llevaban a cabo en la provincia, haciendo notar los buenos oficios en infraestructura y gestión municipal. También el Intendente valoró la instrucción primaria, sosteniendo que había "tenido en Tacna y Arica un desarrollo intensísimo, funcionando con regularidad todas las escuelas de la provincia, aún aquellas que están en los últimos rincones de la sierra" (La Unión, 8 de diciembre de 1922) ${ }^{5}$. En cuanto a su evaluación de los comicios que se avecinarían, fue enfático al señalar:

...cuando llegue el momento de decidir de
los destinos de estas provincias, todos los
hombres de corazón y los extranjeros, que
nos han manifestado en todo momento su
adhesión incondicional, puedan formar el
núcleo que dará el triunfo a nuestro país
en el plebiscito que se llevará a efecto ( $L a$
Unión, 8 de diciembre de 1922).

En otra de las imágenes -tomada en ocasión del licenciamiento de conscriptos y jefes de guarnición del regimiento Rancagua y en honor al cónsul británico Clarence Elliot-, en un plano general con fondo campestre de escenario (como si estuvieran en un estudio fotográfico), se distingue a un grupo vestido de gala donde predominan las figuras de militares y civiles junto con dos "señoritas de sociedad"; todos posan mirando fijamente a la cámara y dan la sensación de protagonizar un acto protocolar (Figura 2). La presencia en esta imagen del coronel Carlos Fernández Pradel, comandante 


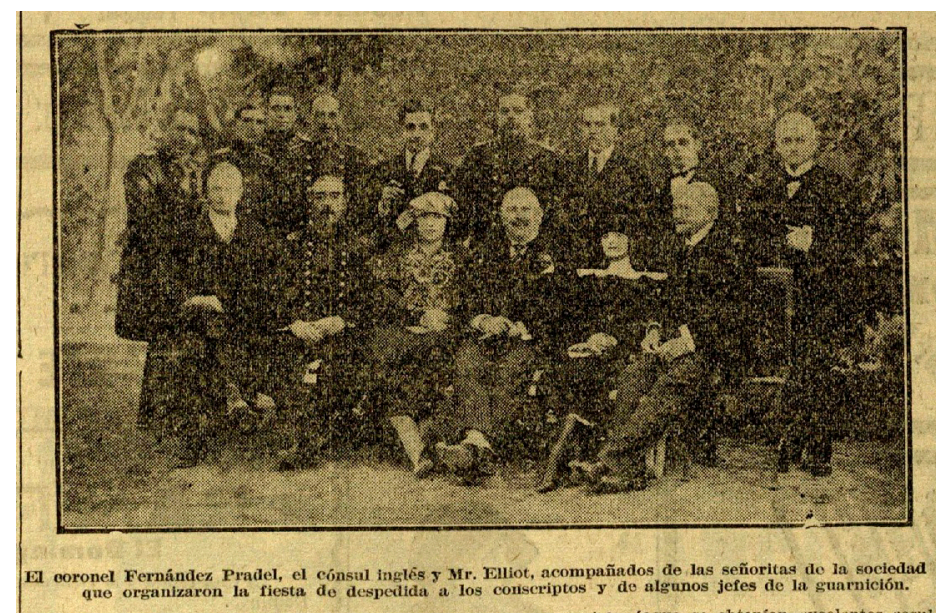

Figura 1. La Unión, 8 de diciembre de 1922.

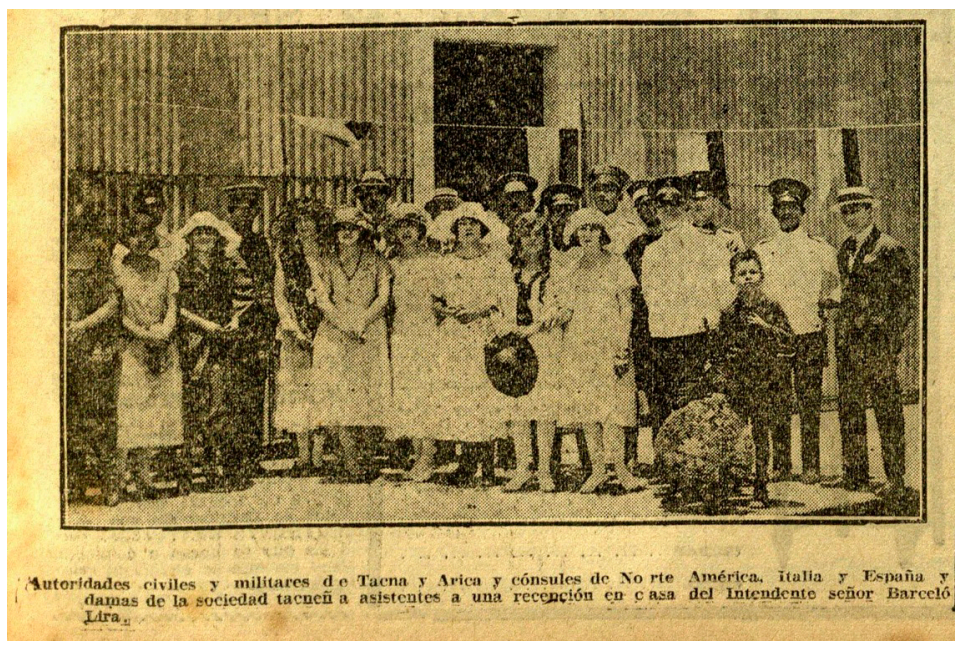

Figura 2. La Unión, 8 de diciembre de 1922.

de la Brigada Combinada, se relacionaba con la entrevista efectuada por el reportero en el cuartel Rancagua, donde había detallado las instalaciones del recinto militar, las que consideró modernas. Fernández Pradel mencionó la moral y la disciplina de la conscripción militar traída del sur, aunque la contrastó con el contingente de la región que acarreaba la herencia de la tuberculosis. Esta enfermedad se podía reconocer en las "miradas vagas, tristes" que revelaban "en sus rostros el tipo indígena de las sierras" (La Unión, 8 de diciembre de 1922) ${ }^{6}$. El desmedro a los habitantes originarios -que se hacía extensivo a la población de los países fronterizos-, cobraba relevancia en este contexto porque se los asemejaba al "sujeto criminal" (León 2016:17) y con esto se hacía alusión a la importancia de la permanencia de la ocupación militar civilizadora del Estado chileno en los territorios en disputa ${ }^{7}$.

Además, la estrecha convivencia entre chilenos y extranjeros, que quiere testificar el reportaje, daba cuenta de una migración deseada en el país y que apelaba, siguiendo postulados sociales darwinistas, a una autoimagen de nación donde prevalecía principalmente el elemento "blanco" europeo, lo que determinaba la excepcionalidad chilena y su superioridad racial (física, intelectual) respecto de otras naciones de la región (Subercaseaux 2010). Esta migración extranjera se intentaba imitar 
y promocionar (León 2016), al demostrarse lo beneficiosa que había sido en la región para el comercio, la extracción minera y la cada vez más creciente industria agropecuaria. Así, por diversos motivos la bien establecida colonia italiana (Díaz et al. 2018) fue de interés para el periodista de $L a$ Unión. A este propósito le había sido de mucha ayuda un antiguo conocido, Andrés Laneri, quien era comerciante, agricultor y agente consular del gobierno de Italia en Tacna, y que lo convidó a la "Societá de Beneficienza Italiana". La ocasión, además, se tornó adecuada para averiguar la opinión acerca del plebiscito. Laneri señaló:

Los miembros de la colonia italiana residente en Tacna serían unos ciento setenta, de los cuales solo un diez por ciento son partidarios del Perú, y el noventa por ciento restante, que se ha radicado en esas regiones desde la ocupación chilena, son consecuentes con sus principios de gratitud para el país que les ha dado franca hospitalidad y que, en caso dado, todos ellos votarían en favor de Chile (La Unión, 8 de diciembre de 1922).

Al siguiente día, Laneri invitó a su quinta a Novoa Orellana y mientras disfrutaban de un café, pudo percatarse de los estrechos vínculos que este mantenía con prominentes comerciantes de Valparaíso, cuestión usual en la colonia italiana (Blaya 1921), al ver recuerdos de familia entre los que estaban "retratos de sus hijas, casadas con los caballeros porteños señor Juan Cambiaso y Arturo Tortello". A continuación, tomaron un coche para conocer las productivas chacras de los miembros de la colonia ubicadas en los callejones tacneños. En una de estas tuvieron la impresión "de pasar por bosques de granados, que servían de cercados a las chacras". Al llegar a la propiedad de los viticultores Baltasari Hermanos, que se extendía en doce hectáreas, vieron innumerables parras altas, "que permitían cultivar en los espacios entre parra y parra, zapallos y hortalizas". No obstante, al seguir la caminata aparecieron sitios baldíos. Laneri le comentó que solo era aprovechable el sesenta por ciento de los terrenos debido a la escasez de agua y "por falta de recursos para los huerteros, que no cuentan con auxilios económicos ni crédito para el desarrollo de sus negocios". Afortunadamente, estaría en vías de desarrollo un gran proyecto de riego que convertiría a los valles "en verdaderos paraísos".
Novoa Orellana procuró interiorizarse de otros rubros de los italianos residentes, para ello se dirigió a las instalaciones de los prestigiosos Cánepa Hermanos, quienes eran grandes industrializadores y negociantes de pieles, lanas de alpaca y llama, además de la compraventa de aceitunas. Allí, pudo pasar revista con Victorio Monteverde, uno de los socios de la compañía, a los almacenes donde el reportero se hizo una idea de los procesos de producción de la lana al observar:

...numerosas indias, [que] con sus hijitos pequeños a su lado, se ocupaban en descarmenar, limpiar y empaquetar la lana de alpaca, hasta dejarla lista para que una poderosa máquina enfardadora, movida por fuerza hidráulica, hiciera los grandes fardos que serán llevados después a los mercados de Liverpool, Génova y Nueva York y otros importantes de Europa ( $\mathrm{La}$ Unión, 14 de diciembre de 1922).

El relato de esta visita por los callejones, los campos cultivados y las factorías, publicado el 14 de diciembre, fue acompañado con una imagen en la que estaban fijados cerca de cuarenta "Voluntarios de la 'Compañía de Pompieri Italia' y miembros de la colonia italiana de Tacna" (Figura 3), dando cuenta de una parte significativa de la comunidad extranjera en la región (Díaz et al. 2018). Este retrato grupal, a diferencia de los anteriores, no incluye a ninguna mujer y está integrado por niños y adultos jóvenes y en la madurez, distribuidos en tres filas y un entorno al aire libre. Entre los sentados, se puede distinguir, por otro medio (Blaya 1921), a Laneri que cobra relevancia, en el orden de las jerarquizaciones, al estar en el centro de la toma. Este tipo de imágenes, que por lo general eran encargadas a fotógrafos profesionales, fueron recurrentes en los inmigrantes debido a un afán de perpetuidad y de memoria; y el deseo de dar a conocer sus ocupaciones laborales o recreativas en los países de donde provenían y que demostraban, en algunas oportunidades, cierto status social alcanzado. Para esto último, las vestimentas cobraban una enorme significación (Giordano 2012). Y para la imagen que nos ocupa, la vestimenta era rigurosamente solemne, estando más de la mitad de los retratados de gala y el resto con sus uniformes de bomberos voluntarios, cuestión que ponía de manifiesto su cohesión identitaria como colectividad y su 


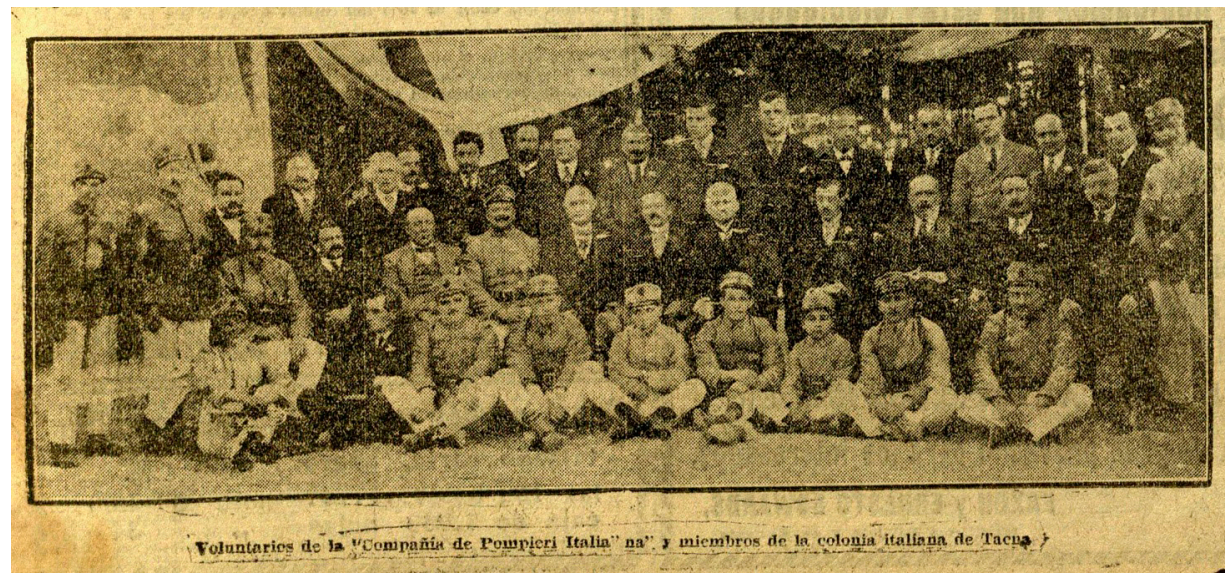

Figura 3. La Unión, 14 de diciembre de 1922.

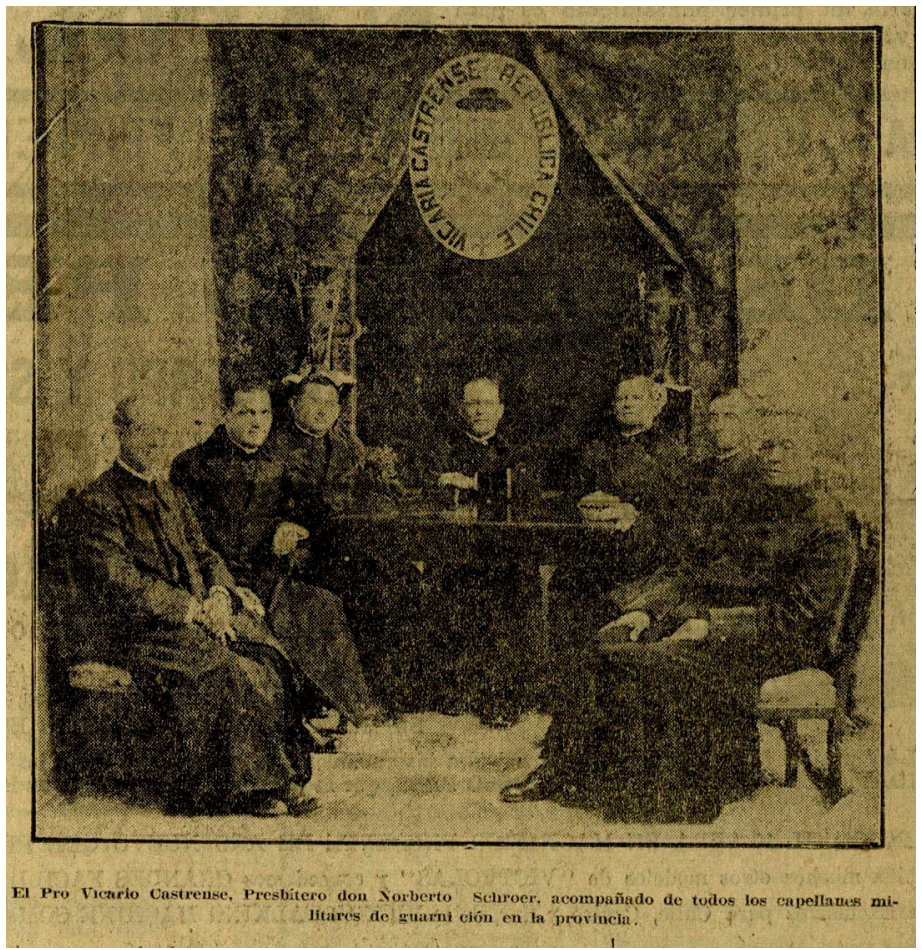

Figura 4. La Unión, 28 de diciembre de 1922.

integración a la nueva sociedad de la que hacían parte en actividades de resguardo propias de su cultura. No se anuncia quiénes son por separado, pero se sabe que pertenecen a una comunidad respetable, que es reconocida en diferentes ámbitos productivos y que se ha logrado establecer en un espacio supuestamente inhóspito. En este sentido, a la colonia se le podría atribuir condiciones de adaptabilidad, arraigadas costumbres e ideas de progreso y civilidad.

Otra de las imágenes grupales escogidas para el reportaje, aparecida el 28 de diciembre, consta de un retrato de religiosos castrenses chilenos aposentados en la provincia de Tacna (Figura 4). La puesta en escena ha sido elaborada cuidadosamente: el cortinaje que hace de fondo, la mesa y las sillas 
en las que están sentados los religiosos en riguroso hábito. Estos posan, encuadrados en una simetría arquitectónica semicircular, mirando fijamente a la cámara, lo que da la sensación de seguridad, orden, energía y unidad. En esta formación se destaca, prevaleciendo el peso institucional, la figura del provicario castrense, presbítero Norberto Schroer, quien, a diferencia de los capellanes, mantiene los brazos cruzados sobre la cubierta de la mesa y ha sido ubicado en el centro de la imagen. Encima del prelado, superpuesto, se divisa una suerte de escudo ovoidal con el lema: "VICARÍA CASTRENSE REPÚBLICA DE CHILE". Estas imágenes de religiosos, que sirvieron incluso como material de promoción y propaganda, fueron comunes en las publicaciones vinculadas al trabajo sacerdotal y a las misiones evangelizadoras en los territorios de nuevas fronteras (Azócar 2014).

Las entrevistas que realizó Novoa Orellana a esta curia militar cumplieron plenamente su objetivo, obteniendo declaraciones y relatos pormenorizados de sus posturas ante la ocupación de los territorios y de la situación de las comunidades andinas que tanto interesaban por ser testigos privilegiados de las acciones muchas veces coercitivas de chilenización (Díaz 2006). Al ser consultado, Schroer fue categórico al señalar que su cometido era llevar a la práctica los deberes sacerdotales y "cumplir las instrucciones que le envía el vicario castrense, obispo de Dodona, Mñor. Rafael Edwards, desde su residencia en la capital". A su vez, el prelado expuso algunas de las dificultades del trabajo de los capellanes, quienes se desplazaban por "extensas regiones bajo climas insoportables" en parajes lejanos. Estas experiencias resultaron una constante para los evangelizadores, las que, en ocasiones, fueron anotadas siguiendo la vertiente colonial de la crónica y cierta "sensibilidad etnográfica", con la intención de dar cuenta del complejo entramado de prácticas culturales de los indígenas (religión, cosmovisiones, relacionamientos sociales, entre otros) y buscando más bien conocer la efectividad de las políticas del Estado chileno para imponer el disciplinamiento en las altiplanicies del norte (Díaz y Casanova 2019:628). En ciertas circunstancias, los arduos recorridos emprendidos por los religiosos podían ser desmesurados, no exentos de peligros, que incluían la explotación de indígenas o el monitorear actividades de extracción minera, como el narrado a La Unión por el capellán Ambrosio Scholz, quien había hecho un reciente viaje a caballo a comunidades situadas en el camino a las sierras entre Bolivia y Perú. En este relato, todo cobraba ribetes simbólicos que recordaban los inicios de la invasión y colonización europea a América Latina. Scholz testimonió:

En el cerro Ucure, en la cumbre del volcán del mismo nombre, a 5.200 metros sobre el nivel del mar, coloqué una cruz de cuatro metros de alto en el punto de unión de las tres repúblicas. La cruz fue llevada al hombro desde Tacna por veinticinco indios hasta colocarla en el volcán. Al pie de la cruz pusimos la siguiente inscripción: Erigida por los capellanes militares Ambrosio Scholz y Manuel Cartagena, el 12 de octubre de 1922 (La Unión, 28 de diciembre de 1922).

\section{Lo rural y lo urbano en la chilenización de la nueva frontera}

El paisaje urbano fue mostrado por el diario porteño en una serie de imágenes de sitios especialmente dedicados a Tacna a los que se aludía en los escritos de Novoa Orellana, quien, al entrar en tren a la ciudad en su primer día de visita, había podido apreciar grandes extensiones cultivadas pertenecientes a la conocida Compañía Industrial Azucarera, algunas quintas, el Club Hípico y cerca de la estación de ferrocarriles le llamó la atención el llegar "a una ciudad provinciana, alejada del centro comercial y por lo tanto abandonada" ( $L a$ Unión, 8 de diciembre de 1922). Estas vistas urbanas tenían como objetivo dejar registro de los lugares representativos que se iban transformando o irradiándose en la fisonomía de calles, plazas y la arquitectura monumental, y que revelaban a estos focos de crecimiento como proyectos urbanísticos con logros del progreso en oposición a lo rural que se le vinculaba al atraso y a la "barbarie".

No obstante, y en plena sintonía con los parámetros de renovación y modernización de los espacios urbanos de la época (Andrade et al. 2017), la intención de los editores de La Unión era hacer notar la condición doble de estancamiento y la viabilidad de una reurbanización de las ciudades de la nueva frontera norte. Por ejemplo, en el caso de los eclesiásticos, se tomó en cuenta imágenes de las iglesias coloniales de San Ramón de Tacna ("en ruinas"), Tarata y Pachia (Figuras 5, 6 y 7), las 


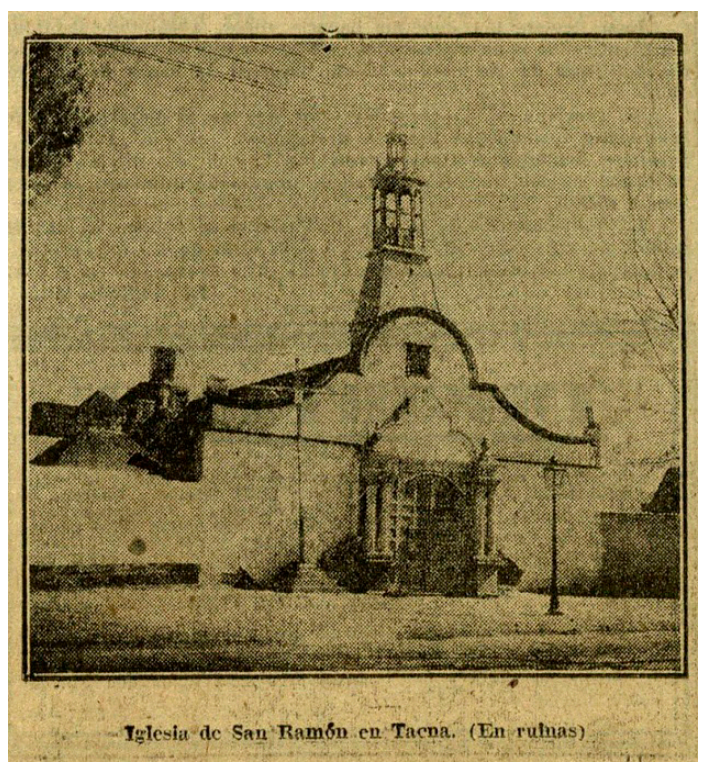

Figura 5. La Unión, 28 de diciembre de 1922.

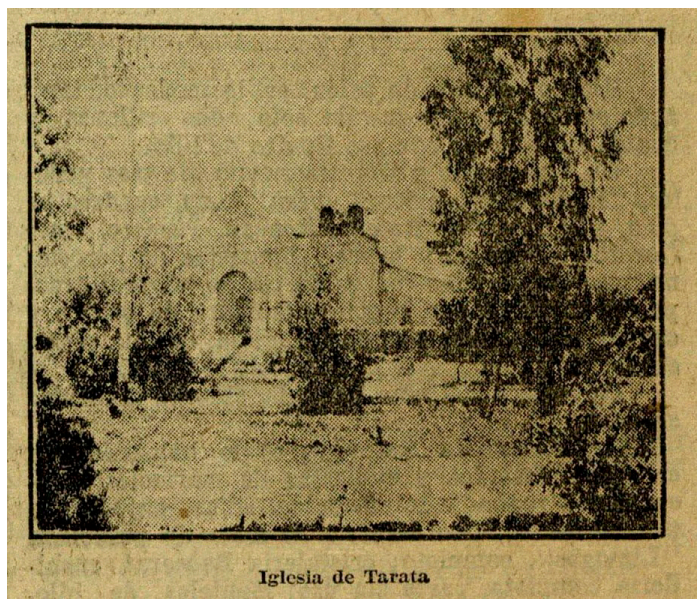

Figura 6. La Unión, 28 de diciembre de 1922.

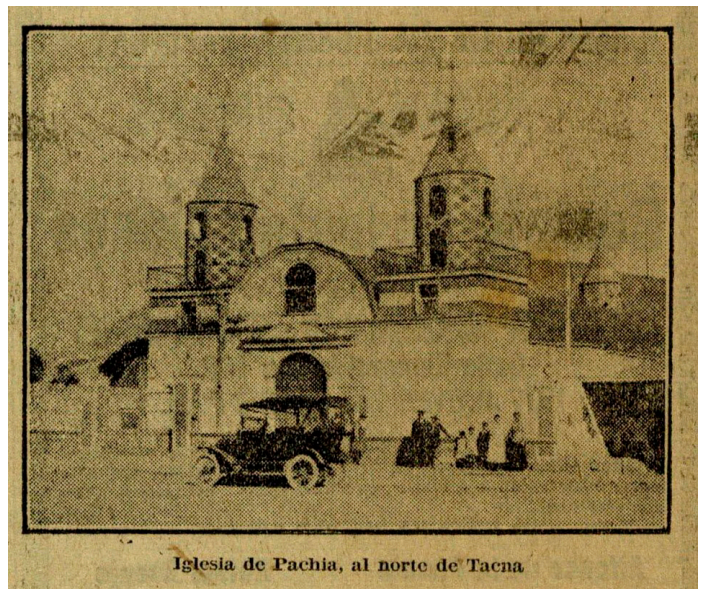

Figura 7. La Unión, 28 de diciembre de 1922. que contrastaban con las icónicas de más reciente construcción diseñadas en Francia: la de Arica y la Catedral tacneña (Figuras 8 y 9), esta última fuera de servicios aunque sus trabajos de refacción al parecer no eran tan complicados (Varas 1922). Por otra parte, las edificaciones tradicionales de Tacna fueron caracterizadas en torno al edificio de la Intendencia como centro de actividades político-administrativas y a una antigua casa de la avenida San Martín ${ }^{8}$ (Figuras 10 y 11); así como los callejones con sus quintas, ubicadas en las periferias, indicaban la presencia de un paisaje semirrural en proceso de ensanchamiento y donde, igualmente, una industria agropecuaria estaba en ascenso y en vías de expansión (Figuras 12 y 13); y estos espacios, además, podían ser utilizados como áreas de recreación (Figura 14). En muchos aspectos, Tacna se había estancado, conviviendo lo antiguo con lo nuevo; es decir, las estructuras arquitectónicas coloniales o semirrurales junto con las infraestructuras sanitarias recientes llevadas a cabo por las políticas chilenizadoras. La ciudad estaba en el momento justo del mejoramiento, para ello se necesitaba únicamente el reforzamiento de las acciones que ya había emprendido el Estado chileno para su profunda modernización.

Adicionalmente a estas vistas de paisaje de entorno citadino, La Unión publicó una entrevista, el 16 de diciembre, difundiendo la visita a Arica y Tacna del diputado Ismael Pereira Iñíguez, presidente de la Compañía Industrial Azucarera. En esta nota periodística, el diputado con entusiasmo hizo referencia a la inauguración de las obras de regadío del valle de Tacna, que consideraba un verdadero acontecimiento ya que significaba:

...transformar aquellas pampas áridas e improductivas, en fértiles campos de cultivo con abundante vegetación. Hasta hoy solo, está ejecutado una parte del proyecto elaborado por la Compañía Azucarera para regar sus pertenencias, que constituirán la más grande fuente de riqueza de Tacna de la cual se beneficiará la República entera (La Unión, 16 de diciembre de 1922).

El diario ilustró con tres imágenes la entrevista (Figura 15). Una de estas es un retrato de ocasión, en un plano medio, que muestra sonrientes, satisfechos, a Pereira Iñíguez y a Barceló Lira. Las restantes son muy similares entre sí y dan cuenta, 


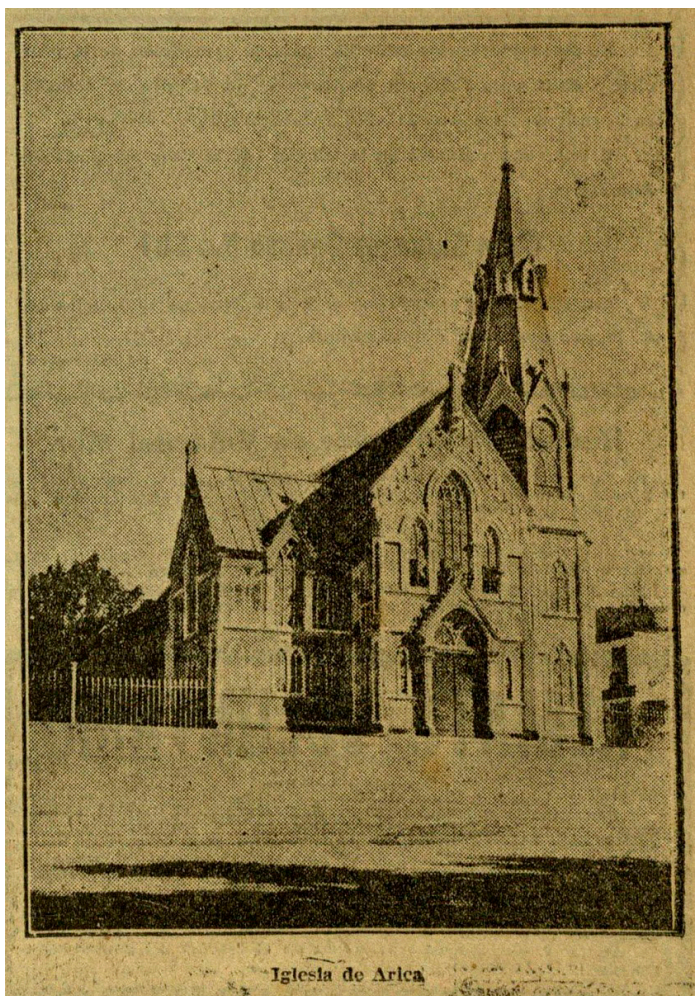

Figura 8. La Unión, 28 de diciembre de 1922.

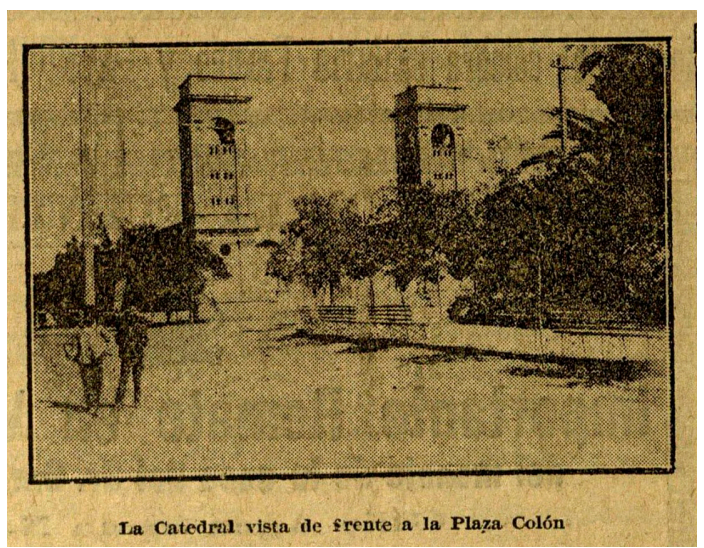

Figura 9. La Unión, 10 de diciembre de 1922.

en un plano general, del inicio de la entrada de las aguas al ingenio azucarero, pudiéndose apreciar a varios sujetos, en poses espontáneas, sobre la estructura de las compuertas del canal. Por sus vestimentas parecieran ser los encargados de las obras y las autoridades, que dominan la escena y de forma simbólica abren las puertas de una nueva era para la provincia.

Así, este tipo de imágenes fueron frecuentes en la prensa que complementaban las noticias

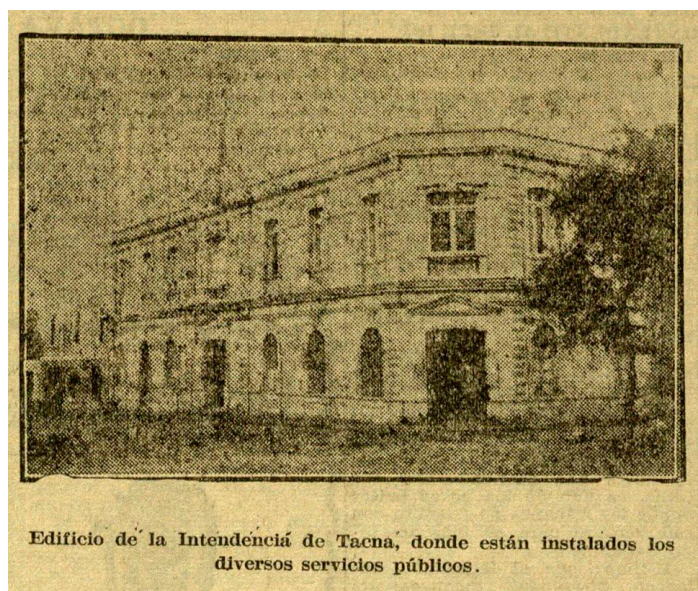

Figura 10. La Unión, 8 de diciembre de 1922.

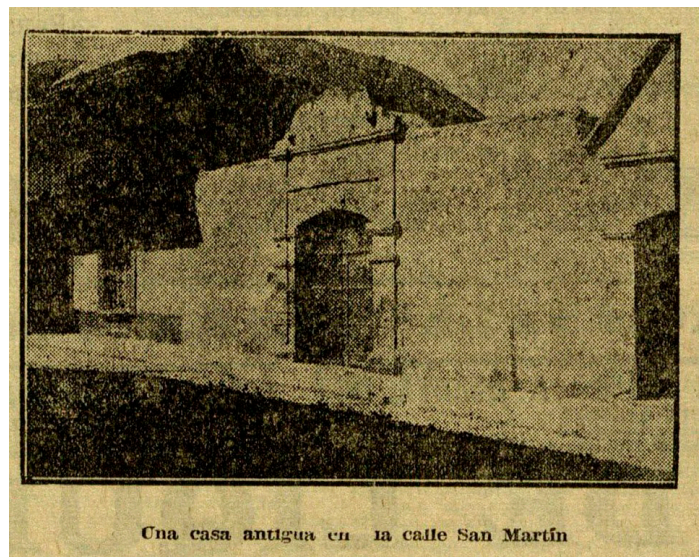

Figura 11. La Unión, 10 de diciembre de 1922.

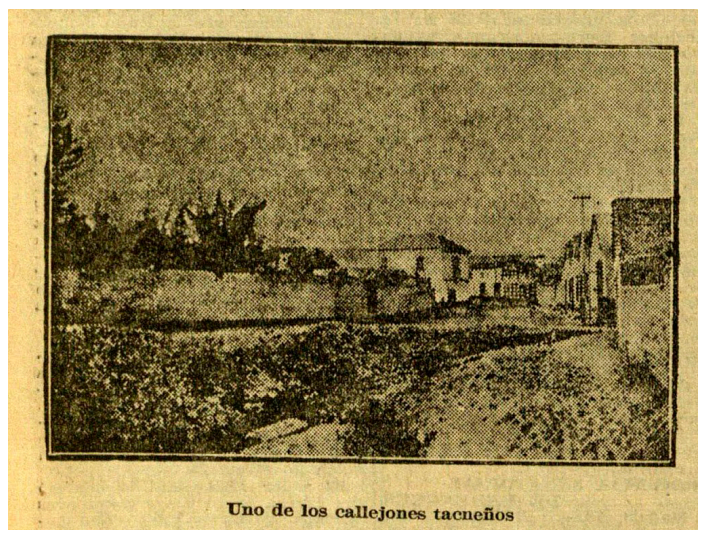

Figura 12. La Unión, 14 de diciembre de 1922.

de inauguraciones de trabajos terminados o en marcha, e intentaban demostrar, promocionando, trascendentes progresos técnicos de infraestructura: alcantarillados, pavimentación de calles, vías de 


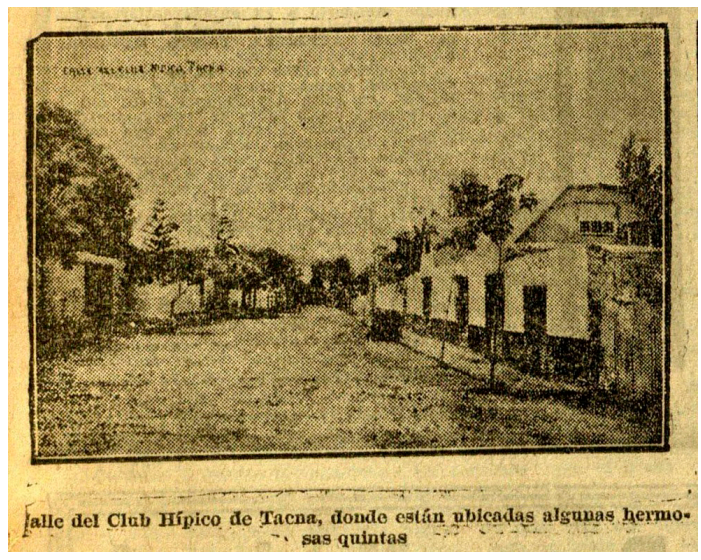

Figura 13. La Unión, 14 de diciembre de 1922.

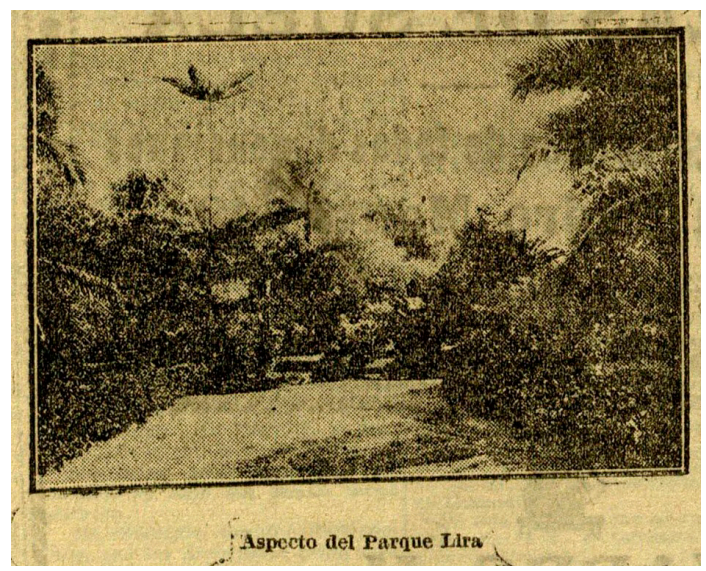

Figura 14. La Unión, 14 de diciembre de 1922.

comunicación terrestre, escuelas y hospitales, entre otros; acciones que habían sido auspiciadas por el Estado chileno (Andrade et al. 2017). Además, los reportajes gráficos cumplieron con la función de testimoniar las modificaciones geográficas y sociales de localidades remotas, que podían cobrar preponderancia al ser aprovechables y así pasar a integrar circuitos mayores de explotación económica y aseguramiento de soberanía (Cornejo 2012).

\section{El ferrocarril internacional Arica-La Paz}

Luego de firmarse el Tratado de Amistad entre Chile y Bolivia (1904), el ferrocarril Arica-La Paz, debido al enorme esfuerzo tecnológico y económico invertido, tuvo una enorme promoción en la prensa desde su misma puesta en marcha en 1906, así como en su inauguración en 1913; convirtiéndose en una

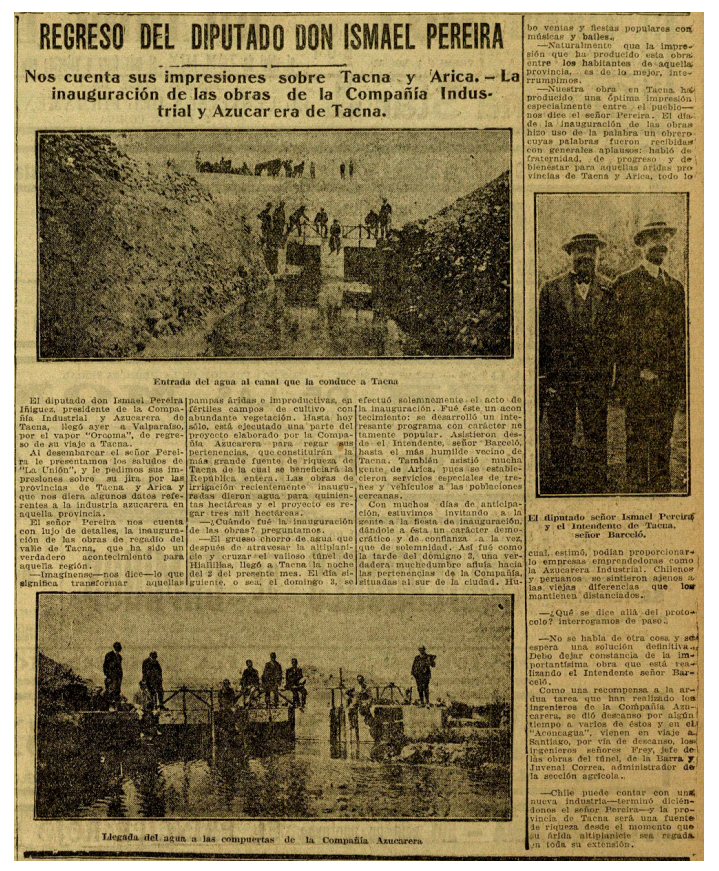

Figura 15. La Unión, 16 de diciembre de 1922.

obra chilenizadora/modernizadora emblemática. En especial los magazines de la época publicaron reportajes gráficos con numerosas vistas del ferrocarril, las que centraron su atención en la destreza de los trabajos de ingeniería que fueron valorados como una "epopeya" en un paisaje "agreste", lo que le otorgaba al "conjunto de imágenes la idea del triunfo del progreso técnico y científico ante los obstáculos de la naturaleza" (Ruz et al. 2016:122-123).

El diario porteño quiso graficar la incursión de Novoa Orellana al altiplano dando inicio a su colaboración con una imagen del Morro de Arica (Figura 16), el que ya se había convertido en una de las visualizaciones nacionalistas más recurrentes y por ello en atracción turística (León 1915). Otras páginas fueron ilustradas con representaciones muy similares entre sí que mostraban en el escarpado paisaje cordillerano, sin la presencia humana, los rieles triples de tecnología de cremallera que eran utilizados como "enganche" de los convoyes en pronunciadas pendientes cordilleranas (Figuras 17 y 18).

Las impresiones del reportero, a la manera de un conocedor del estilo del viajero de la época, le hicieron admirar las pequeñas chacras, algunas de nombres patrióticos como "Puro Chile"9. El tren contaba con las comodidades acordes con la 


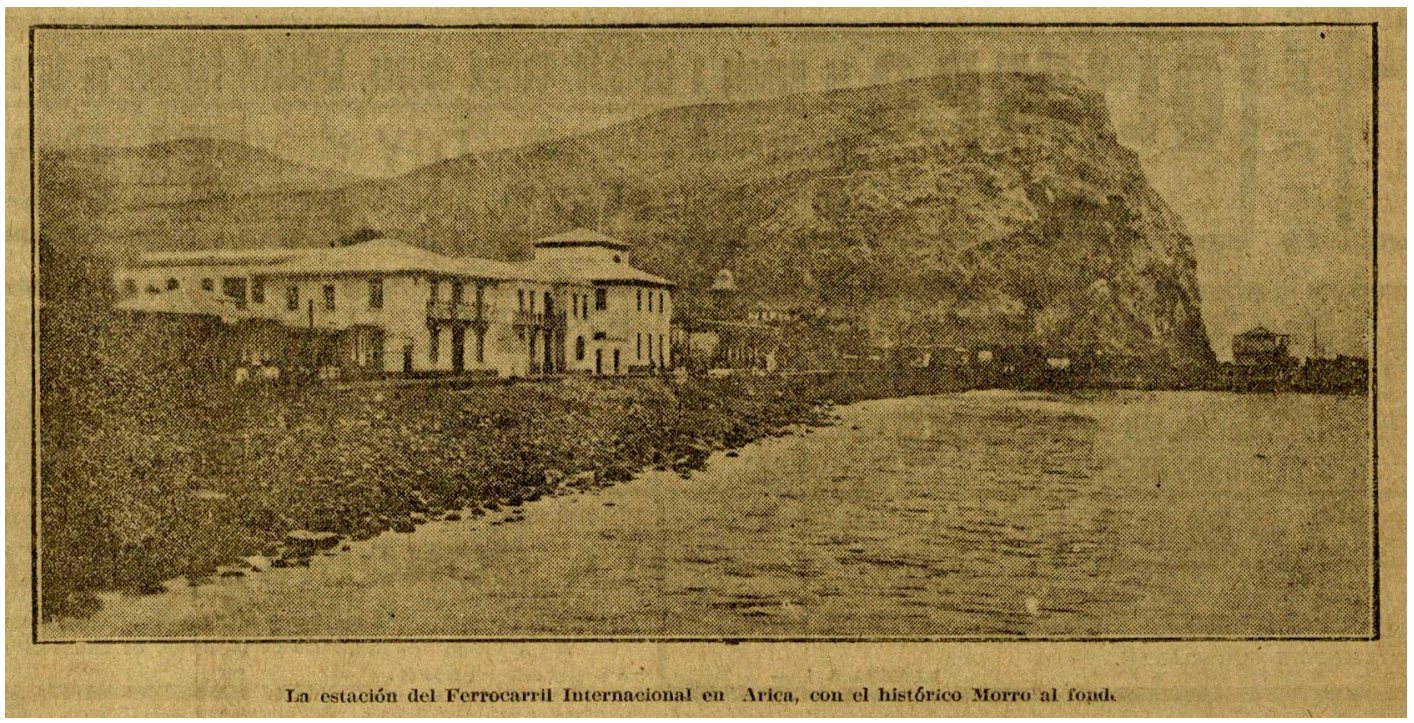

Figura 16. La Unión, 17 de diciembre de 1922.

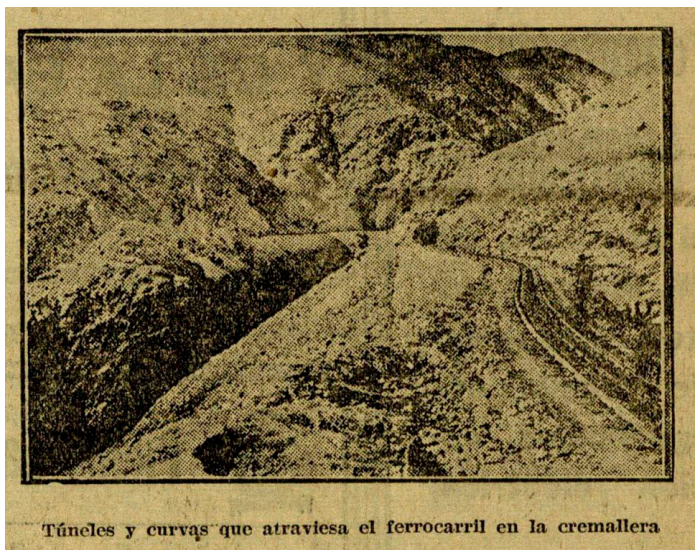

Figura 17. La Unión, 17 de diciembre de 1922.

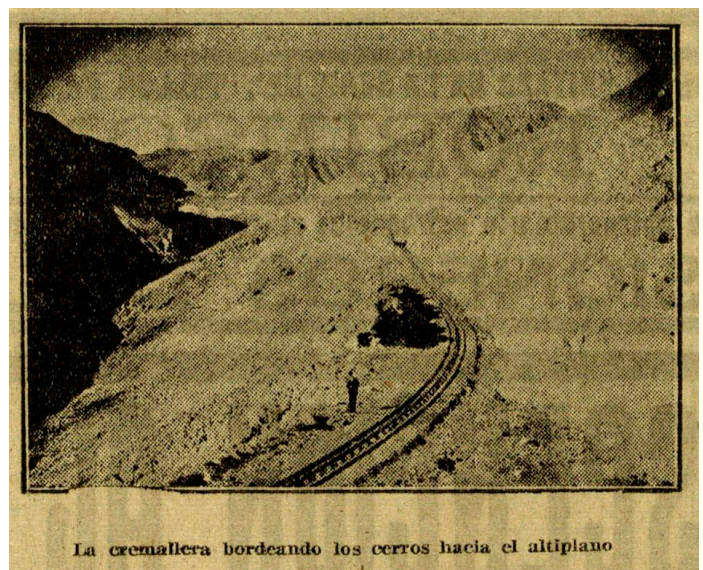

Figura 18. La Unión, 19 de diciembre de 1922. nueva "cultura del viajero" que se había impuesto como una necesaria condición de los trayectos en ferrocarril (Bustos 2007:39), lo que pudo comprobar a la hora de la comida en el coche comedor, que estaba ocupado "por familias extranjeras y pasajeros bolivianos y chilenos" con los que disfrutó de un menú al nivel del "mejor de los hoteles del país, por su preparación y selección". Al amanecer del siguiente día, luego de dormir en una cama del coche dormitorio, contempló el paisaje montañoso de altura, que le dio la sensación de entrar a una era geológica remota, "cuyas mesetas parecían que en algunos siglos atrás hubieran sido aglomeraciones de bosques que la acción de los miles de años había convertido en piedra". Al hacer una parada en la estación Calacoto, se hizo una idea de los habitantes de un pueblo indígena, quienes vivían en "ranchos cuyos techos son todos de paja" y en un lugar destacado había "una antigua iglesia con techo de tejas y arquitectura del tipo colonial". También le llamó la atención un monumento de barro que resultó ser

...una huaca incaica, donde los antepasados depositaban sus muertos (...). Junto a los cadáveres se ponían ídolos de plata, utensilios de casa, las joyas del extinto y los objetos que la piedad de sus deudos y amigos querían colocarle como recuerdo y siguiendo los tradicionales sentimientos de religiosos de esas épocas (La Unión, 17 de diciembre de 1922) ${ }^{10}$. 


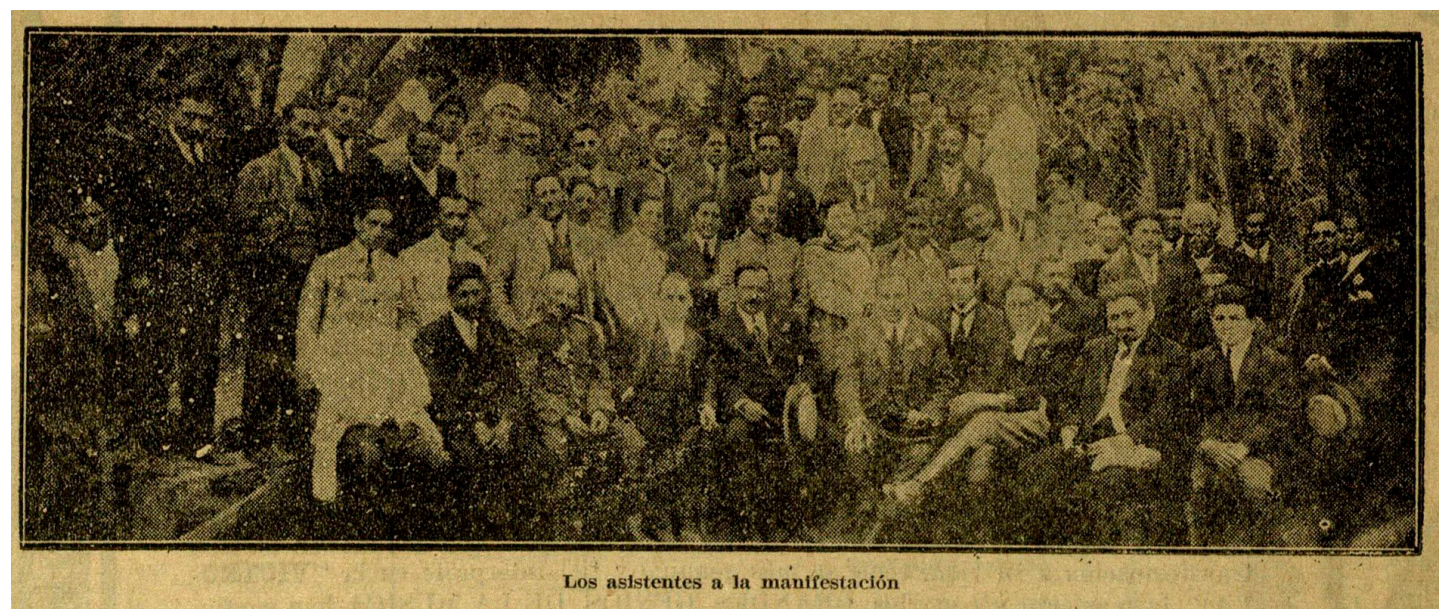

Figura 19. La Unión, 30 de diciembre de 1922.

Una vez de vuelta a Arica, el reportero recorrió la Maestranza de Chinchorro y observó deficiencias en la estructura de los talleres; sin embargo su apreciación general fue positiva al ver que "se hacían en esos momentos algunos trabajos de fundición de piezas grandes y estaban preparándose los modelos para ejecutar un trabajo", que le resultó "propio de los grandes establecimientos industriales" ( $L a$ Unión, 19 de diciembre de 1922).

Para el cierre del reportaje a la provincia de Tacna y Arica, el diario porteño reprodujo una nota de sociales publicada por La Aurora de Arica, que consistió en el agasajo ofrecido por los agricultores de Azapa, el domingo 26 de diciembre, al gobernador Emiliano Bustos León, los alcaldes Luis Schmidt y Arturo Quirós, y otras autoridades locales. En el transcurso del almuerzo, Novoa Orellana fue "obligado a hablar", para ello pronunció "un vibrante discurso en que puso de relieve su elocuencia y su clara visión" (La Unión, 30 de diciembre de 1922). Los más de cincuenta comensales presentes fueron retratados en un gran plano. La imagen anecdótica cobra relevancia por su capacidad de lograr articularse con el resto de los retratos grupales organizados en esta suerte de álbum de la visita al territorio de nueva frontera. En la última visualización, se aprecia a civiles y unos pocos militares vestidos formalmente, con paisaje campestre de fondo. En esta toma (Figura 19), donde la presencia de la multitud se torna esencial, estarían todos los que guían el proceso de modernización y es precisamente una ocasión privilegiada para mostrar cohesión y voluntad de dominio. Es una comunidad que, de alguna manera, está allí invitando al lector y le ofrece el territorio en disputa, y es por intermedio de La Unión que se hace una realidad posible.

\section{Comentarios finales}

Nuestro acercamiento al reportaje realizado por La Unión de Valparaíso a Tacna y Arica, ha podido dar cuenta de una lectura particular en torno a un periodo gravitante de conflictividad postguerra del Pacífico, el que se ubica en los inicios de las Conferencias de Washington en 1922, y que tenía como centro de tensiones políticas y diplomáticas a Chile y Perú ante un posible plebiscito para dirimir lo que era considerado como una nueva frontera norte.

Apuntemos, entonces, que la postura editorial de La Unión, a diferencia de otros medios que en ocasiones tuvieron una actitud virulenta, fue de un tenor más subrepticio, menos frontal, pero que no dejó de ser coincidente con las políticas de chilenización que apelaban a la supuesta superioridad del país en relación con Perú y con otros países de la región, lo que fue explicitado al hacer notar la capacidad modernizadora auspiciada por el Estado chileno mediante la visibilización de obras emblemáticas de progreso material.

En este sentido, la estrategia periodística de La Unión -debido a su adopción de innovadoras concepciones de los medios de comunicación masivos- consistió en elaborar una sofisticada puesta en escena promocional, en la que se dio relevancia a ciertos paralelismos y semejanzas culturales vinculadas a las sociabilidades que eran practicadas por las elites de Arica y Tacna y las del centro del país, 
intentando con esto probar lo conveniente del nuevo territorio en disputa al evidenciar sus características aptas para la habitabilidad, la explotación económica (agropecuaria, minera, industrial) y la seguridad brindada por el ejército de ocupación chileno.

Consignemos, además, que el género reportaje fue de gran eficacia para la representación de informaciones periodísticas de complejo y largo alcance, lo que en este diario de Valparaíso tuvo un correlato entre la redacción de los textos y la escogencia de imágenes fotográficas como una potente demostración persuasiva. Esto último configuró una suerte de álbum familiar de la visita a la nueva frontera, que sintonizaba con otros mecanismos identitarios nacionales y que fueron utilizados como discursos hegemónicos por la clase dominante de la época.

\section{Referencias Citadas}

Aguirre, L.

1946 El libro de Valparaíso: 1536-1946. Imprenta Salesiana, Valparaíso.

Andrade, P., Franceschini, C., Mellado, L., Vega, R., Sánchez, M., Cárdenas, A. y Bravo, C.

2017 Estado en obras. La construcción de Chile. Siglos $X I X-X X$. Dibam, Santiago.

Azócar, A.

2014 Así son... así somos. Discurso fotográfico de capuchinos y salesianos en la Araucanía y la Patagonia. Ediciones Universidad de la Frontera, Temuco.

Barros, L. y Vergara, X.

2007 El modo de ser aristocrático. Ariadna Ediciones, Santiago.

Barthes, R.

1986 Lo obvio y lo obtuso. Imágenes, gestos, voces. Paidós, Barcelona.

Blaya, Joaquín

1921 El progreso italiano en Chile. Imprenta y Litografía La Ilustración, Santiago.

Bustos, A., León, S., Vergara, B. y Padilla, M. 2007 Historia de la postal en Chile. PUCV, Valparaíso.

Cádiz, F.

2013 'La 'chilenización' en el Norte y Sur de Chile: una necesaria revisión”. Cuadernos Interculturales Vol. 11 (20):11-43.

Chartier, R.

1992 El mundo como representación. Estudios sobre historia cultural. Gedisa, Barcelona.

Collier, S. y Sater, W.

1999 Historia de Chile, 1808-1994. Cambridge University Press, Madrid.

Cornejo, $\mathrm{T}$.

2012 "La fotografía como factor de modernidad: territorio, trabajo y trabajadores en el cambio de siglo". Historia Vol. I (45):5-48.

Díaz, A. y Pizarro, E.

2004 "Tacna y Arica en tiempos del Centenario (1910)". Diálogo Andino (24):29-38.

Díaz, A.

2006 "Aymaras, peruanos y chilenos en los Andes ariqueños: Resistencia y conflicto frente a la chilenización del norte de Chile". Revista de Antropología Iberoamericana Vol. 1 (2):296-310

Díaz, A., Galdames, L. y Ruz, R.

2013 "Aymaras y plebiscitarios. Los indígenas andinos, la chilenización y las identidades en la frontera cultural (Putre
1920-1929)". Si Somos Americanos. Revista de Estudios Transfronterizos Vol. XIII (2):81-111.

Díaz, A., Ruz, R. y Sánchez, E.

2018 "Presencia italiana en el extremo norte chileno. Inmigración y sociedad fronteriza peruano-chilena (Arica 1880-1930)". Interciencia Vol. 43 (11):751-757.

Díaz, A. y Casanova, F.

2019 “Crónica de la chilenización. La religiosidad andina a través del relato del padre Julio Ramírez Ortiz. Sierra de Arica, 1922-1931". Chungara. Revista de Antropología Chilena Vol. 51 (4):627-638.

Fernández, H.

2018 Una revisión al fotolibro chileno. Fundación Sud Fotográfica, Santiago.

Galdames, L., Ruz, R. y Díaz, A.

2018 Imaginarios nacionales de la frontera norte chilena. Revistas magazinescas (1883-1930). Ediciones Universidad de Tarapacá, Arica.

Galdames, L., Ruz, R. y Meza, M.

2018 "Imaginario nacional en revistas de la frontera zona norte de Chile postguerra del Pacífico: Ariqueña (Arica, 1923) y Torbellino (Tacna, 1924)". En Imaginarios nacionales de la frontera norte chilena. Revistas magazinescas (1883-1930), L. Galdames, R. Ruz y A. Díaz, pp. 11-22. Ediciones Universidad de Tarapacá, Arica.

Giordano, M.

2012 "Fotografía, testimonio oral y memoria. (Re)presentaciones de indígenas e inmigrantes del Chaco (Argentina)". Memoria Americana 20 (2):295-321.

González, S., Maldonado, C. y McGee, S.

1993 "Las ligas patrióticas". Revista de Ciencias Sociales (2):54-72.

González, S.

2008 La Llave y el candado. El conflicto entre Perú y Chile por Tacna y Arica (1883-1929). LOM, Santiago.

Henríquez, $M$.

2013 "Oferta comercial, publicidad e imágenes en torno a la elite. Valparaíso, 1900-1940”. Universum Vol. 1 (28):149-172.

Lagos, G.

1981 Historia de las fronteras de Chile. Los tratados de límites con Perú. Editorial Andrés Bello, Santiago.

Leiva, G.

2013 "Imágenes en tensión: enclaves y estereotipos históricos en la construcción de la memoria visual chilena". Patrimonio e Memoria Vol. 9 (2):43-56.

León, J.

1915 Chile al día: álbum gráfico de vistas de Chile. Hume \& Walker Editores, Santiago. 
León, M.

2016 Construyendo un sujeto criminal. Criminología, criminalidad y sociedad en Chile. Dibam, Santiago.

Navarrete, J. A.

2009 Fotografía en América Latina. Ensayos de crítica histórica. Fundación para la Cultura Urbana, Caracas.

Pizarro, E.

2006 "Los visitadores de escuelas: agentes del Estado docente en el extremo norte de Chile (1884-1897)". Diálogo Andino (27):75-84.

Pratt, M.

1997 Ojos imperiales. Literatura de viajes y transculturación. Universidad de Quilmes, Buenos Aires.

Rinke, $S$.

2002 Cultura de masas: reforma y nacionalismo en Chile 1910-1931. Dibam, Santiago.

Ruz, R., Galdames, L., Díaz, A. y Meza, M.

2016 "Relatos visuales de una 'Arica chilena'. Los magazines de la Editorial Zig-Zag (1902-1930)”. Diálogo Andino (50):115-132.

Ruz, R., Meza, M. y Galdames, L.

2018 "La Comisión Plebiscitaria Tacna-Arica a través de las caricaturas de la revista Sucesos (1925-1926)". En Imaginarios nacionales de la frontera norte chilena. Revistas magazinescas (1883-1930), L. Galdames, R. Ruz y A. Díaz, pp. 105-138. Ediciones Universidad de Tarapacá, Arica.
Ruz, R., Galdames, L. y Meza, M.

2019 "Magazines Zig-Zag: reportajes gráficos y alteridad en torno al indígena de la nueva frontera norte chilena (19051930)". Estudios Atacameños. Arqueología y Antropología Surandinas (61):135-153.

Santa Cruz, E.

2002 "Modernización y cultura de masas en el Chile de principios del siglo veinte: El origen del género magazine". Comunicación y medios (13):169-184.

Santa Cruz, E

2014 Prensa y sociedad en Chile, siglo XX. Editorial Universitaria, Santiago.

Subercaseaux, B.

2010 "Raza y nación: ideas operantes y políticas públicas en Chile, 1900-1940". En Nacionalismos e identidad nacional en Chile. Siglo XX, Vol. I, editado por G. Cid y A. San Francisco, Vol. 1, pp. 69-91. Ediciones Centro de Estudios Bicentenario, Santiago.

Tagg, J.

2005 El peso de la representación. Ensayos sobre fotografías e historias. Gustavo Gili, Barcelona.

Varas, C.

1922. Tacna y Arica bajo la soberanía chilena. Editorial La Nación, Santiago.

\section{Fuentes}

La Unión de Valparaíso.

\section{Notas}

1 En este sentido, nos ha sido de gran ayuda las perspectivas temáticas y metodológicas de los trabajos pioneros en este campo y que tienen, a diferencia de nuestra fuente de prensa, a las revistas magazine como centro de sus investigaciones: Galdames, Ruz y Díaz (2018) y Ruz et al. (2019).

2 Según Sergio González (2008:67), para la época que nos ocupa, "se puede afirmar con toda seguridad que ni Perú ni Chile tenían la seguridad de ganar la consulta. Lo único seguro era que Perú ganaba en Tacna y Chile en Arica, pero el plebiscito era uno solo e incluía a ambas provincias".

3 A estas seis entregas de Novoa Orellana, se le sumaron otras dos notas de ocasión, las que hemos incorporado a nuestro trabajo.

4 Un buen ejemplo de esto es el libro de vistas fotográficas de J. León (1915).

5 El interés chileno por establecer una continuidad educativa en la región comienza desde los fines mismos de la Guerra del Pacífico (Pizarro 2006). En este sentido, el Estado se propuso implementar, para la chilenización educativa, "la cultura nacional en las escuelas primarias rurales a través de la castellanización y la alfabetización en los poblados rurales, que, en este momento, eran sinónimo de peruanidad o incivilización bajo una lógica Sarmenteana" (Díaz 2006:300).

6 En cuanto a la noción estereotipada, por tanto prejuiciosa y racista acerca de los indígenas como pueblos moribundos o en extinción, ver: Ruz et al. (2019).
7 En otro reportaje a la región, realizado un poco antes, se señala que la "permanencia de elementos militares le da mucha vida a la localidad y le aporta una considerable riqueza de que aprovecha todo el vecindario" (Varas 1922:279).

8 La imagen había sido publicada en Varas (1922:278), donde se señala que allí había pernoctado el Libertador Simón Bolívar en su estadía por la región. La falta de profundización del reportaje, al señalarse únicamente que es una "casa antigua", da a entender que la precisión no era necesaria, ni requerida por el lector del diario.

9 Debido a las circunstancias plebiscitarias, se produjo un notorio rebrote nacionalista en la región, esto fue evidenciado por diversas manifestaciones que incluyeron, entre otras, la propaganda difundiendo los "avances en infraestructura, higiene y salubridad pública" de la administración chilena, así como la sustitución de denominaciones peruanas renombrándolas por las de héroes patrios chilenos (Díaz 2013:89).

10 Por lo general, en la prensa chilena se caracterizó al indígena de la región andina (Perú y Bolivia), haciendo alusión "a 'tipos fronterizos', 'tipos de provincia' o 'tipos populares' que normalmente acercaban al lector a lo advertido por el corresponsal o a lo editado por la revista respecto de la realidad social y étnica de espacios desconocidos a los que se daba cobertura" (Ruz et al. 2019:142). 